\title{
Determination of in situ degradation parameters and feeding level of pineapple (Ananas comosus L.) cannery by-product to Hanwoo steers
}

\author{
Yongjun $\mathrm{Choi}^{1}$, Keunkyu Park ${ }^{1}$, Sangrak Lee ${ }^{1}$, and Youngjun $\mathrm{Na}^{1, *}$
}

* Corresponding Author: Youngjun Na Tel: +82-2-450-3696, Fax: +82-2-458-2124,

E-mail: ruminoreticulum@gmail.com

${ }^{1}$ Department of Animal Science and Technology, Konkuk University, Seoul 05029,

Korea

ORCID

Yongjun Choi

https://orcid.org/0000-0002-5759-4108 Keunkyu Park

https://orcid.org/0000-0002-8328-3522 Sangrak Lee

https://orcid.org/0000-0002-8905-0770

Youngjun $\mathrm{Na}$

https://orcid.org/0000-0002-4643-0191

Submitted Feb 11, 2020; Revised May 20, 2020; Accepted Aug 4, 2020
Objective: The objectives of this study were to determine the in situ degradation parameters and appropriate feeding level of pineapple cannery by-products (PCB) based on the growth performance and blood parameters of growing Hanwoo (Bos taurus coreanae) steers fed various levels of PCB.

Methods: Two ruminally cannulated Holstein cows were used for in situ disappearance rate measurements. Nylon bags $(5 \times 10 \mathrm{~cm}, 45 \mu \mathrm{m}$ pore size) filled with $5 \mathrm{~g}$ of PCB in triplicate were inserted into the ventral sac of the two cannulated Holsteins cows and incubated for $0,2,4,8,16,24$, and $48 \mathrm{~h}$. A total of 16 castrated growing Hanwoo steers $(12.5 \pm 0.5$ months old, $302.9 \pm 25.7 \mathrm{~kg}$ of initial body weight [BW]) were used for the experiment. Animals were stratified by initial BW and then randomly assigned to one of four experimental diets (0\%, $1.5 \%, 3.0 \%$, or $6.0 \%$ of PCB, on the dry matter [DM] basis) fed for $91-\mathrm{d}$, including $30-\mathrm{d}$ of adaptation.

Results: Soluble fraction $a$ of DM and crude protein (CP) was $61.9 \%$ and $86.0 \%$, fraction $b$ of DM and CP was $32.7 \%$ and $11.2 \%$, and indigestible fraction $c$ of DM and CP was 5.4\% and $2.8 \%$. The $6.0 \%$ PCB feeding group showed lower productivity compared to animals in the other treatments. Increasing the dietary level of PCB did not alter DM intake, but it was numerically lowest in the $6.0 \%$ feeding group. The gain to feed ratio was linearly decreased by increasing of PCB. The quadratic broken-line test estimated that 2.5\% (DM basis) was the maximum feeding level of PCB in growing Hanwoo steers $\left(y=0.103-0.001 \times[1.245-\mathrm{x}]^{2}\right.$, $\left.\mathrm{R}^{2}=0.18\right)$.

Conclusion: Diets containing up to $2.5 \%$ PCB can be fed to growing Hanwoo steers without adverse effects on growth performance.

Keywords: Beef Cattle; By-product; Feeding Level; Pineapple; Hanwoo; Steer

\section{INTRODUCTION}

The use of human-inedible by-products as feed ingredients can potentially diminish the dependence on grains and pulse crops in the livestock industry [1] as well as solve environmental problems associated with improper waste disposal [2]. Pineapple (Ananas comosus L.) is widely grown in tropical and subtropical regions and it has been processing large quantities of fresh pineapple fruit as slices, chunks, crush, jam, or juice. Among these, canned fruit is the main product of the pineapple industry worldwide [3]. Because only part of pineapple fruit is generally utilized for cannery processing, pineapple processing factories generate considerable amounts of by-products, such as skin, crown ends, bud ends, and cores [4]. Although pineapple cannery by-products (PCB) do not completely meet the nutrient requirements of animals as a sole feed source [5], they have typically been used as a feed ingredient in the diets of ruminants, swine, poultry, and fish [6]. Although previous stud- 
ies have sought to determine the effect of PCB on the growth performance of beef cattle [7-9], most of these studies were conducted using survey methodology rather than by performing specifically designed animal experiments. Consequently, there remains a need for further research to determine the appropriate feeding level of PCB in beef cattle diets. Therefore, the objectives of the present study were to determine i) the effect of PCB level on the growth performance and blood parameters of growing Hanwoo (Bos taurus coreanae) steers, and ii) the appropriate level of PCB in beef cattle diets.

\section{MATERIALS AND METHODS}

\section{Animal care}

The experiment was carried out in an experimental facility of Konkuk University at Chungju-si, Chungcheongbuk-do, Korea (latitude $36.99^{\circ}$ and longitude $127.93^{\circ}$ ). All research protocols were approved by Konkuk University Animal Care and Use Committee (Approval number: KU16139).

\section{Pineapple cannery by-product}

The PCB was obtained from Shinsegae Food Processing Facility (Icheon, Korea). The PCB which used in the current analyses contains the skin, crown ends, bud ends, and cores (Figure 1). The composition of lipids and amino acids was presented as Supplementary Table A1 and A2. The PCB was discharged about 165 tons per month in the facility, it has been stored in a container with a leachate outlet in room temperature. The $\mathrm{PCB}$ used in the experiment showed a $\mathrm{pH}$ of 3.90 with the leachate removed (Figure 1). The test was performed that changes in properties of PCB by time (every day for 7 d) and temperature $\left(0^{\circ} \mathrm{C}, 23^{\circ} \mathrm{C}\right.$, and $30^{\circ} \mathrm{C}$ ) before formulated to experimental feed. In the temperature of $23^{\circ} \mathrm{C}$ and $30^{\circ} \mathrm{C}$, the flavor and surface color of the PCB was changed after 5 $\mathrm{d}$, the fungus appeared after $7 \mathrm{~d}$, and it did not show appearance change at $0 \mathrm{~d}$ except moisture evaporation. The PCB was used for experimental feed within 5 days after dumped based on the test result.

\section{In situ procedure}

Two ruminally cannulated Holstein cows were used for in situ disappearance rate measurements. The cows were fed commercial concentrate pellets (dry matter [DM], 92.3\%; crude protein [CP], 14.5\% of DM; neutral detergent fiber [NDF], $31.8 \% \mathrm{DM}$; acid detergent fiber [ADF], 11.6\% DM; ether extract [EE], 3.7\% DM; ash, 7.5\% DM) and rice straw (DM, 92.1\%; CP, 5.5\% DM; NDF, 62.1\% DM; ADF, 36.6\% DM; EE, $1.4 \% \mathrm{DM}$; ash, $5.2 \% \mathrm{DM}$ ) with ad libitum access to feed during the experiment. The PCB samples were dried and milled to pass through a 3-mm screen (Wiley Mill; Thomas Scientific, Swedesboro, NJ, USA). The DM, ash, CP, EE, ADF, NDF,
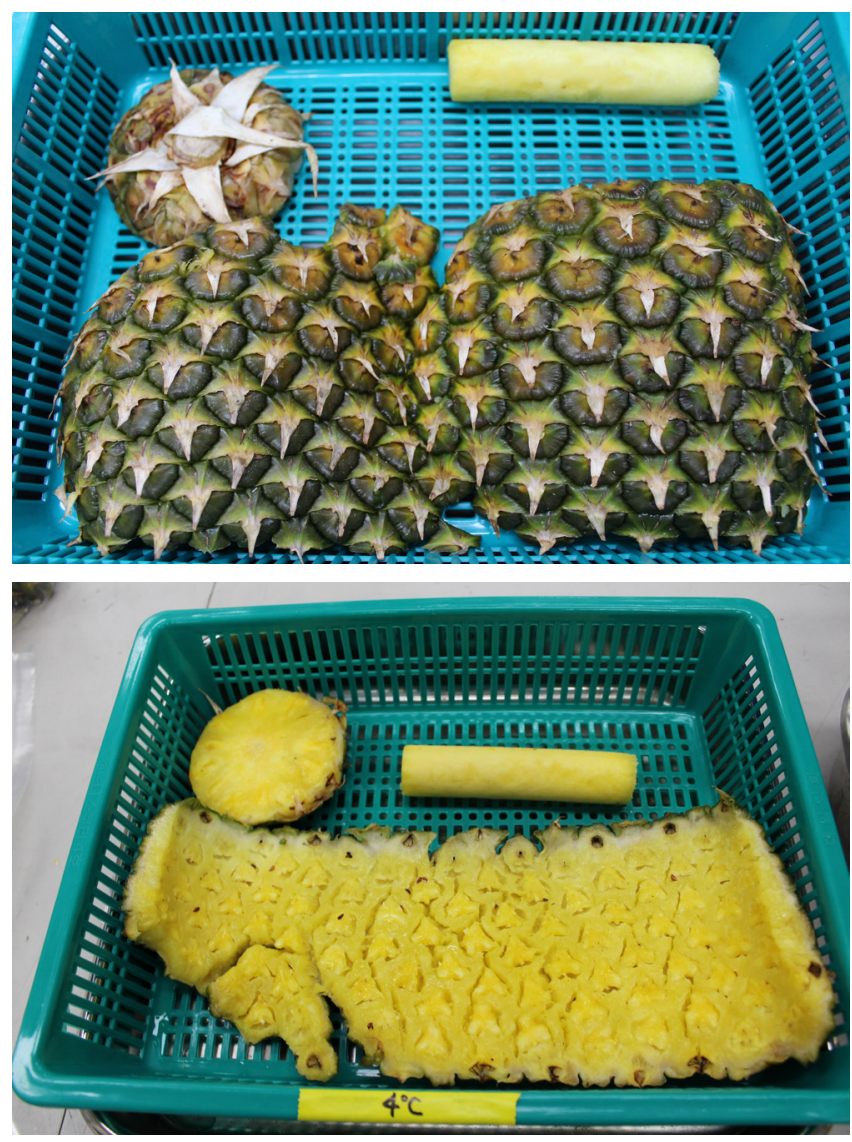

Figure 1. Photos of the skin, bud end, and core of pineapple cannery by-product generated from food processing factory.

non-fiber carbohydrate (NFC), and water-soluble carbohydrate (WSC) concentrations in PCB were 9.2\%, 4.9\%, 5.7\%, $1.2 \%, 17.7 \%, 39.4 \%, 48.8 \%$, and $5.4 \%$ of DM, respectively. Nylon bags $(5 \times 10 \mathrm{~cm}, 45 \mu \mathrm{m}$ pore size; R510, ANKOM Inc., NY, USA) filled with $5 \mathrm{~g}$ of PCB in triplicate were inserted into the ventral sac of two cannulated Holsteins cows and incubated for $0,2,4,8,16,24$, and $48 \mathrm{~h}$ according to NRC [10]. After incubation, the nylon bags were rinsed in tap water, dried at $60^{\circ} \mathrm{C}$, and then weighed for $\mathrm{DM}$ and $\mathrm{CP}$ analysis. Degradation was assessed using the formula of Ørskov [11]:

$$
\mathrm{P}=a+b\left(1-e^{-c t}\right)
$$

where $\mathrm{P}$ is the actual degradation after time $t ; a$ is the intercept of the degradation curve at time zero; $b$ is the potential degradability of the component of the protein which will, in time, be degraded; $c$ is the rate constant for the degradation of $b$; and $t$ is time. For estimation of the fraction $b$, regression analysis was performed using SAS PROC REG (Version 9.4, SAS Institute Inc., Cary, NC, USA).

The effective degradability (ED) of DM and CP was calculated using the following equation: 


$$
\mathrm{ED}=a+(b \times c) /(c+k)
$$

where $k$ is the estimated rate of outflow from the rumen and $a, b$, and $c$ are the same parameters as described above. The ED was estimated as ED2, ED5, and ED8 assuming rumen solid outflow rates of $0.02,0.05$, and $0.08 / \mathrm{h}$, which are representative of low, medium, and high feeding intake, respectively.

\section{Animals and experimental design}

Sixteen growing Hanwoo (Bos taurus coreanae) steers (12.5 \pm 0.5 months old, $302.9 \pm 25.7 \mathrm{~kg}$ of initial body weight [BW]) were used for the experiment. All steers were vaccinated for foot and mouth disease before the experiment. Animals were stratified by initial BW and then randomly assigned to one of four experimental diets. Each pen was equipped with individual electronic feeding gates for individual feeding. The experimental diets contained $0 \%, 1.5 \%, 3.0 \%$, or $6.0 \% \mathrm{DM}$ of PCB (Table 1) and it was formulated every week for the experiment. The experimental unit was an individual animal. Experimental diets were formulated to meet or exceed the nutrient requirements of the Korean Feeding Standard for Hanwoo and daily weight gain of steers was predicted 0.8 $\mathrm{kg} / \mathrm{d}$ on the control diet (Presented on the basis of $300 \mathrm{~kg}$ of BW, $7.1 \mathrm{~kg}$ of DM intake (DMI), and total digestible nutrients value 68.0) [12]. Animals were fed twice a day at $09: 00 \mathrm{~h}$ and 17:00 $\mathrm{h}$ ad libitum, with $5 \%$ to $10 \%$ refusals. The experiment was continued for $91 \mathrm{~d}$, including $30 \mathrm{~d}$ for diet adaptation and $61 \mathrm{~d}$ for data collection. The BW (unshrunk basis) was measured before morning feeding at $\mathrm{d} 0,30,60$, and 91 of the experimental periods. Offered diets and orts were weighed daily for DMI measurement.

\section{Chemical analysis}

All samples were dried and ground to pass through a 1-mm screen (Wiley Mill; Thomas Scientific, USA). All samples were dried in an air drying oven at $60^{\circ} \mathrm{C}$ for $48 \mathrm{~h}$ to analyze $\mathrm{DM}$ [13]. Ash (method 942.05), CP (method 990.03), and EE (method 920.39) were analyzed in duplicate according to the standard methods of the AOAC [13]. ANKOM fiber analyzer 200 (ANKOM Technology Crop., Macedon, NY, USA) was used for NDF (method 2002.04) and ADF (method 973.18) analyses. The NFC content of feeds was calculated by subtraction of CP, NDF, EE, and ash from 100.

Table 1. Ingredients and chemical composition of experimental diets for the growing Hanwoo steers

\begin{tabular}{|c|c|c|c|c|}
\hline \multirow{2}{*}{ Items } & \multicolumn{4}{|c|}{ Pineapple cannery by-product level (\% DM) } \\
\hline & 0 & 1.5 & 3.0 & 6.0 \\
\hline \multicolumn{5}{|l|}{ Ingredients } \\
\hline Corn, cracked (\% DM) & 18.5 & 17.7 & 16.9 & 15.4 \\
\hline Soybean meal (\% DM) & 2.4 & 2.4 & 2.3 & 2.3 \\
\hline Corn gluten meal (\% DM) & 15.2 & 15.2 & 15.2 & 15.2 \\
\hline Wheat meal (\% DM) & 0.7 & 0.7 & 0.7 & 0.7 \\
\hline Coconut kernel meal (\% DM) & 0.7 & 0.7 & 0.6 & 0.6 \\
\hline Palm kernel meal (\% DM) & 1.3 & 1.3 & 1.3 & 1.3 \\
\hline Alfalfa, hay (\% DM) & 12.5 & 12.5 & 12.5 & 12.5 \\
\hline Klein grass, hay (\% DM) & 12.5 & 12.5 & 12.5 & 12.5 \\
\hline Water $(\%)$ & 35.1 & 26.4 & 17.6 & 0.0 \\
\hline \multicolumn{5}{|l|}{ Chemical composition } \\
\hline DM (\%) & 59.8 & 59.8 & 59.8 & 59.8 \\
\hline Ash (\% DM) & 7.9 & 7.9 & 8.0 & 8.0 \\
\hline $\mathrm{CP}(\% \mathrm{DM})$ & 15.2 & 15.2 & 15.2 & 15.2 \\
\hline EE (\% DM) & 2.9 & 2.9 & 2.9 & 2.8 \\
\hline ADF (\% DM) & 21.0 & 21.0 & 20.9 & 20.7 \\
\hline NDF (\% DM) & 44.0 & 44.0 & 44.0 & 43.9 \\
\hline NFC (\% DM) & 30.0 & 30.0 & 30.0 & 30.0 \\
\hline TDN (\% DM) & 68.2 & 68.2 & 68.2 & 68.3 \\
\hline
\end{tabular}

DM, dry matter; CP, crude protein; EE, ether extract; ADF, acid detergent fiber; NDF, neutral detergent fiber; NFC, non-fiber carbohydrate; TDN, total digestible nutrients.

${ }^{1)}$ Vitamin E, $500 \mathrm{IU} / \mathrm{kg} ; \mathrm{Fe}, 50,000 \mathrm{mg} / \mathrm{kg} ; \mathrm{Cu}, 6,720 \mathrm{mg} / \mathrm{kg} ; \mathrm{Mn}, 24,000 \mathrm{mg} / \mathrm{kg} ; \mathrm{Zn}, 30,000 \mathrm{mg} / \mathrm{kg}$. 
Blood sampling and analysis

Blood samples were collected at $\mathrm{d} 70$ and $\mathrm{d} 90$ of the experiment for serum analysis. Blood samples $(15 \mathrm{~mL})$ were collected via the jugular vein using 18-gauge needles and transferred to silicon-coated serum tubes (Vacutainer, BD, Franklin Lakes, NJ, USA). Serum samples were separated by centrifugation at $2,000 \times g$ at $4^{\circ} \mathrm{C}$ for $20 \mathrm{~min}$ and stored at $-80^{\circ} \mathrm{C}$ until subsequent analysis. These samples were analyzed using an automated chemical analyzer (Model 7180 Clinical Analyzer, Hitachi Ltd, Tokyo, Japan). Reagents for analyses of albumin, glutamic-oxaloacetic transaminase (GOT), glutamic pyruvate transaminase, blood urea nitrogen, creatine, triglycerides, high-density lipoproteins, low-density lipoproteins, calcium, inorganic phosphorus, magnesium, and non-esterified fatty acids were purchased from JW Medical (Seoul, Korea).

\section{Statistical analysis}

Data were analyzed using SAS PROC MIXED (Version 9.4, SAS Institute Inc., Cary, NC, USA). The model included PCB level as the fixed effect. Orthogonal contrast for linear and quadratic effect was performed using polynomials determined by SAS PROC IML. Treatment effects were considered significant at $\mathrm{p}<0.05$, and trends were considered at $0.05 \leq \mathrm{p}<0.10$. Quadratic broken-line regression analysis was conducted using SAS PROC NLIN [14]. Gain to feed (G:F) ratio was used as the response criterion.

\section{RESULTS}

The $\mathrm{DM}$ and $\mathrm{CP}$ degradation parameters, and the ED values of PCB are presented in Table 2. Soluble fraction $a$ of DM and $\mathrm{CP}$ was $61.9 \%$ and $86.0 \%$, whereas fraction $b$ of DM and $\mathrm{CP}$ was $32.7 \%$ and $11.2 \%$, and indigestible fraction $c$ of DM and $\mathrm{CP}$ was $5.4 \%$ and $2.8 \%$.

There was a linear decrease in body weight gain (BWG; $p$ $=0.006$ ), average daily gain (ADG; $p=0.006$ ), and G:F ratio $(p=0.008)$ with increasing of dietary PCB level (Table 3$)$. The DMI tended to linearly $(\mathrm{p}=0.051)$ decrease with increasing
Table 2. In situ degradation parameters of pineapple cannery byproduct

\begin{tabular}{lcc}
\hline \multirow{2}{*}{ Items $^{1)}$} & \multicolumn{2}{c}{ Degradation parameter } \\
\cline { 2 - 3 } & Dry matter & Crude protein \\
\hline$a(\% \mathrm{DM})$ & 61.9 & 86.2 \\
$b(\% \mathrm{DM})$ & 32.7 & 11.2 \\
$c\left(h^{-1}\right)$ & 0.079 & 0.072 \\
ED2 $(\% \mathrm{DM})$ & 88.0 & 94.7 \\
ED5 $(\% \mathrm{DM})$ & 81.9 & 92.6 \\
ED8 $(\% \mathrm{DM})$ & 78.2 & 91.3 \\
\hline
\end{tabular}

DM, dry matter.

1) $a$, the fraction of dry matter and crude protein at the initiation of incubation; $b$, the fraction of dry matter and crude protein insoluble but degradable in the rumen; $c$, the rate constant $\left(\mathrm{h}^{-1}\right)$ of disappearance of fraction $b$; ED, effective degradability at three ruminal passage rates (i.e., $0.02,0.05$, and $0.08 / \mathrm{h}$ ).

of dietary PCB level. As the level of the PCB increased, serum albumin concentration linearly $(\mathrm{p}=0.010)$ decreased with increasing of dietary PCB level (Table 4). Serum GOT concentration was linearly $(\mathrm{p}=0.025)$ increased with increasing of dietary PCB level. The quadratic broken-line test estimated that $3.25 \% \mathrm{DM}$ (21.1\%, on an as-fed basis) was the maximum feeding level of PCB for growing Hanwoo steers $(y=0.103+$ $0.001 \times[1.245-\mathrm{x}]^{2}, \mathrm{R}^{2}=0.18 ; \mathrm{p}=0.283$; Figure 2).

\section{DISCUSSION}

Because the pineapple by-products generally contain high water-soluble and moisture contents like other fruit by-products, they have the potential to readily decay [15]. Although there are certain procedures for decreasing the moisture content of PCB, such as sun-drying or artificial drying, sun-drying is impracticable during the rainy season and artificial drying generates additional expenses and it also requires special facilities. It has long been known that the wet total mixed ration (TMR) feeding system is a relevant strategy when using highmoisture by-product ingredients such as brewer's grain, citrus pulp, and grape pomace. However, little work has been conducted to determine the suitability of high-moisture PCB as

Table 3. Effect of pineapple cannery by-product on dry matter intake, body weight, average daily gain, and gain to feed ratio of the growing Hanwoo steers

\begin{tabular}{|c|c|c|c|c|c|c|c|}
\hline \multirow{2}{*}{ Items } & \multicolumn{4}{|c|}{ Pineapple by-product level (\% DM) } & \multirow{2}{*}{ SEM } & \multicolumn{2}{|c|}{ p-value } \\
\hline & 0 & 1.5 & 3.0 & 6.0 & & Linear & Quadratic \\
\hline Initial BW (kg) & 297.6 & 311.9 & 303.9 & 298.4 & 14.0 & 0.861 & 0.563 \\
\hline Final BW (kg) & 352.1 & 369.0 & 355.3 & 333.6 & 16.9 & 0.306 & 0.395 \\
\hline $\mathrm{BWG}(\mathrm{kg})$ & 54.5 & 57.1 & 51.4 & 35.3 & 4.7 & 0.006 & 0.186 \\
\hline $\operatorname{ADG}(\mathrm{kg} / \mathrm{d})$ & 0.91 & 0.95 & 0.86 & 0.59 & 0.08 & 0.006 & 0.189 \\
\hline $\mathrm{DMI}(\mathrm{kg} / \mathrm{d})$ & 8.92 & 8.96 & 8.76 & 7.57 & 0.49 & 0.051 & 0.365 \\
\hline G:F ratio & 0.10 & 0.11 & 0.10 & 0.08 & 0.01 & 0.008 & 0.170 \\
\hline
\end{tabular}

DM, dry matter; SEM, standard error of the mean; BW, body weight; BWG, body weight gain; ADG, average daily gain; DMI, dry matter intake; G:F, gain to feed. 
Table 4. Effect of pineapple cannery by-product on serum blood parameters of the growing Hanwoo steers (experiment 2)

\begin{tabular}{|c|c|c|c|c|c|c|c|}
\hline \multirow{2}{*}{ Items } & \multicolumn{4}{|c|}{ Pineapple cannery by-product level (\% DM) } & \multirow{2}{*}{ SEM } & \multicolumn{2}{|c|}{ p-value } \\
\hline & 0 & 1.5 & 3.0 & 6.0 & & Linear & Quadratic \\
\hline Albumin (g/dL) & 3.7 & 3.6 & 3.6 & 3.3 & 0.10 & 0.010 & 0.431 \\
\hline GOT (U/L) & 76.5 & 85.3 & 90.0 & 91.0 & 3.88 & 0.025 & 0.169 \\
\hline $\mathrm{GPT}(\mathrm{U} / \mathrm{L})$ & 30.5 & 29.8 & 33.5 & 30.5 & 1.71 & 0.799 & 0.341 \\
\hline $\operatorname{BUN}(\mathrm{mg} / \mathrm{dL})$ & 15.8 & 12.5 & 17.8 & 18.5 & 2.88 & 0.306 & 0.769 \\
\hline Creatine $(\mathrm{mg} / \mathrm{dL})$ & 1.3 & 1.1 & 1.1 & 1.2 & 0.07 & 0.655 & 0.052 \\
\hline Triglycerides (mg/dL) & 23.3 & 15.3 & 15.3 & 16.3 & 3.47 & 0.274 & 0.182 \\
\hline $\mathrm{HDL}(\mathrm{mg} / \mathrm{dL})$ & 205.8 & 201.0 & 193.5 & 198.5 & 11.17 & 0.641 & 0.571 \\
\hline $\mathrm{LDL}(\mathrm{mg} / \mathrm{dL})$ & 32.0 & 33.3 & 32.3 & 31.3 & 3.46 & 0.807 & 0.807 \\
\hline Calcium (mg/dL) & 10.4 & 10.4 & 10.5 & 9.9 & 0.21 & 0.097 & 0.264 \\
\hline Inorganic P (mg/dL) & 9.4 & 9.3 & 8.3 & 9.4 & 0.57 & 0.894 & 0.239 \\
\hline $\mathrm{Mg}(\mathrm{mg} / \mathrm{dL})$ & 3.0 & 3.0 & 2.8 & 3.0 & 0.10 & 0.791 & 0.147 \\
\hline $\mathrm{NEFA}(\mathrm{mmol} / \mathrm{L})$ & 145.7 & 155.7 & 147.2 & 206.1 & 33.83 & 0.223 & 0.562 \\
\hline
\end{tabular}

DM, dry matter; SEM, standard error of the mean; GOT, glutamic-oxaloacetic transaminase; GPT, glutamic pyruvic transaminase; BUN, blood urea nitrogen; HDL, high-density lipoproteins; LDL, low-density lipoproteins; NEFA, non-esterified fatty acid.

an ingredient for TMR diets. Although PCB have been used as a roughage source replacer in some experiments because of their large amounts of fibrous contents [16,17], the high amounts of non-fibrous carbohydrate in PCB should also be considered because of its readily degradable characteristics in the rumen.

The degradation characteristics of feed ingredients are effectively used to anticipate rumen fermentation [11]. To our knowledge, only one scientific study has examined the in situ degradability of pineapple by-product [18]. However, it is difficult to directly compare the results of the present study with those of the previous study [18] because they used a mixture of PCB and elephant grass silage for the in situ procedure, whereas in the current study, we used PCB as the sole treatment. In addition, in situ procedures are affected by various factors such as pore size $[19,20]$, test animal diet, and sampling schedules [21], or bag surface area ratio [22, 23 ]. Because the rapid rumen degradation results in rumen acidosis $[24,25]$, PCB has to be used appropriately with consideration of their highly degradable DM and CP contents. Piao et al proposed that the synchronization of energy and nitrogen supply can improve the efficiency of rumen microbial protein synthesis [26]. Therefore, suggest that the rapidly degradable nitrogen sources to improve efficiency

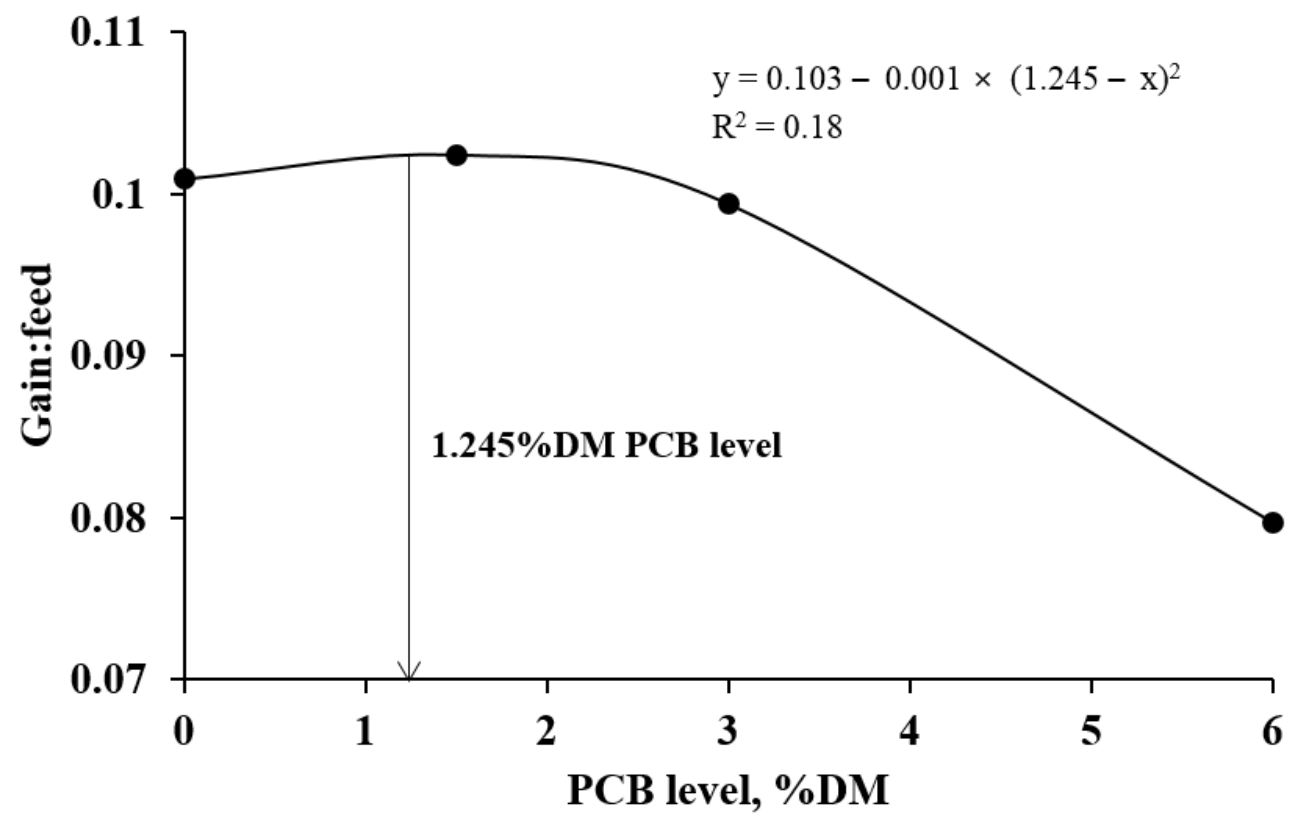

Figure 2. The quadratic broken-line analysis of gain:feed (G:F; $R^{2}=0.18 ; p=0.283$ ) as a level of pineapple cannery by-product (PCB) in growing Hanwoo steers (dry matter basis, $n=4$ for each regression line). 
of the rumen fermentation should also be used in diets containing PCB due to their rapidly degradable characteristics. The kinetics of the ruminal degradation of $\mathrm{PCB}$, which were estimated in the current study can provide values for more complex dynamic digestion models and subsequent animal trials.

Growth performance is directly affected by DMI, as a consequence of nutrient supply. In the current experiment, although DMI was not significantly affected by the dietary level of PCB, the numerically lowest value of DMI during the entire experimental period was observed for diets containing 39\% PCB. Basically, voluntary feed intake and the productivity of ruminants might decrease due to the high moisture content if an excessive amount of PCB is used in the diet [27]. In the previous study, the DMI decreased linearly with an increasing level of pineapple by-product in the diet as a substitute for corn silage [9]. In general, PCB contains a high level of WSC and non-fiber carbohydrate contents. Previous studies have reported that although a high concentration of WSC in the diet can increase palatability $[28,29]$, it can also decrease ruminal $\mathrm{pH}$ and the activity of fiber-using bacteria [30]. Therefore, it would appear that the rapid degradation characteristics of $\mathrm{PCB}$ in the rumen may alter the ruminal microbial community, thereby decreasing total nutrient digestibility. In addition, there was no significant difference in the growth performance of steers during period 1 ( $\mathrm{d} 0$ to 30 ), whereas in period 2 , BWG and ADG decreased linearly with an increasing level of PCB. This indicate that the adverse effects of excessive feeding of PCB in steer diets could gradually increase with time [31].

There was reported that pineapple by-products can be used to replace 50\% (as-fed basis) of roughage sources for dairy cattle ration without any adverse effect [32]. In a beef cattle trial, $30 \%$ to $100 \%$ (as-fed basis) of fresh pineapple by-products has been used as a roughage substitute in beef cattle diet in local production regions [4]. However, this study has certain limitations because the results are based on farm survey data, whereas specifically designed animal experiments are needed to determine the appropriate feeding level of PCB. To our knowledge, there has been only one specifically designed study that sought to determine the effect of pineapple by-product level in beef cattle except for previous experiment [31]. It determined that silage containing pineapple by-products have an effect on the growth performance of bulls [9]. These authors concluded that the DM, organic matter, and metabolized energy intake were linearly decreased when pineapple by-product silage was gradually increased $(0 \%$ to $31 \% \mathrm{DM}$ ) in the diet as a substitute for corn silage whereas BWG and ADG were not affected. Although the results of this study indicated that pineapple by-product silage did not affect growth performance, it is difficult to directly compare these findings with those of the current study because Prado et al [9] used small breed animals ( $328 \mathrm{~kg}$ of initial BW at 20 months old), whereas we used animals of $302.9 \mathrm{~kg}$ of initial BW at 12.5 months old.

On the basis of the quadratic broken-line test performed in the present study, the recommended levels of the PCB for growing Hanwoo steer can be set at between $0 \%$ and 3.25\% $\mathrm{DM}$ (FCR used as a criterion) in the diet. Although the findings of the present study provide a framework for the determination of appropriate levels of dietary PCB, further work is needed to establish the long-term effects, from growing phase to slaughter, of PCB on the growth performance and carcass traits of beef cattle.

In conclusion, the use of PCB in ruminant diets has to be carefully considered because they have high moisture and rapidly degradable DM and $\mathrm{CP}$ contents. In addition, rapidly degradable nitrogen sources should be included in diets containing PCB due to their high amounts of soluble carbohydrates. In conclusion, PCB can be fed at levels up to 3.0\% DM of the steer diet without adverse effect on growth performance or blood parameters. However, considering the lower performance of the 6.0\% DM PCB feeding group in the present study, an excessive level of PCB is not recommended. On the basis of the quadratic broken-line test, which uses the FCR as a response criterion, diets containing up to $3.25 \%$ DM PCB can be used for growing Hanwoo steers.

\section{CONFLICT OF INTEREST}

We certify that there is no conflict of interest with any financial organization regarding the material discussed in the manuscript.

\section{ACKNOWLEDGMENTS}

This work was carried out with the support of "Cooperative Research Program for Agriculture Science and Technology Development (Project No. PJ013838012020)" Rural Development Administration, Republic of Korea.

\section{REFERENCES}

1. Karlsson J, Spörndly R, Lindberg M, Holtenius K. Replacing human-edible feed ingredients with by-products increases net food production efficiency in dairy cows. J Dairy Sci 2018;101:7146-55. https://doi.org/10.3168/jds.2017-14209

2. Grasser LA, Fadel JG, Garnett I, Depeters EJ. Quantity and economic importance of nine selected by-products used in California dairy rations. J Dairy Sci 1995;78:962-71. https:// doi.org/10.3168/jds.S0022-0302(95)76711-X

3. Tran AV. Chemical analysis and pulping study of pineapple crown leaves. Ind Crops Prod 2006;24:66-74. https://doi.org/ 
10.1016/j.indcrop.2006.03.003

4. Featherstone S. A complete course in canning and related processes: volume 3 processing procedures for canned food products. Sawston, Cambridge, UK: Woodhead Publishing; 2015.

5. Ribeiro MER, Rodrigues RC, Costa NL. Use of agribusiness residues in animal feed. In: Proceedings of the Annual Meeting of the Sociedade Brasileira de Zootecnia 30th 1993; 1993 July 30: Rio de Janeiro, Brazil. Rio de Janeiro, Brazil: Sociedade Brasileira de Zootecnia; 1993. p. 509.

6. Sanewski GM, Bartholomew DP, Paull RE. The pineapple: botany, production, and uses. Wallingford, Oxfordshire, England: CABI; 2018.

7. Geoffroy F, De Lavigne P, Mahé Y, Saminadin G, Georges CPU. Use of ensilage from pineapple cannery waste for fattening lambs and young bulls. Rev Elev Med Vet Pays Trop 1984;37:326-30. https://doi.org/10.19182/remvt.8417

8. Devendra C. Non-conventional feed resources in Asia and the Pacific. Bangkok, Thailand: FAO/APHCA publication; 1985.

9. Prado IN do, Lallo FH, Zeoula LM, Caldas Neto SF, Nascimento WG do, Marques J de A. Bulls performance in feedlot with levels of substituting corn silage by pineapple by-products silage. Rev Bras Zootec 2003;32:737-44. https://doi.org/10. 1590/S1516-35982003000300026

10. Committee on Animal Nutrition, National Research Council. Nutrient requirements of dairy cattle. Washington, DC, USA: National Academies Press; 2001.

11. Ørskov ER, McDonald I. The estimation of protein degradability in the rumen from incubation measurements weighted according to rate of passage. J Agric Sci 1979;92:499-503. https://doi.org/10.1017/S0021859600063048

12. KFSE Council. Korean feeding standard for Korean cattle (Hanwoo). Sejong, Korea: National Livestock Research Institute; 2017.

13. Cunniff P. AOAC International. Official methods of analysis of AOAC International. Arlington, VA, USA: AOAC International; 2002.

14. Robbins KR, Saxton AM, Southern LL. Estimation of nutrient requirements using broken-line regression analysis. J Anim Sci 2006;84 (Suppl 13):E155-65. https://doi.org/10.2527/2006. 8413_supplE155x

15. Ahmadi F, Lee WH, Oh Y-K, Park K, Kwak WS. Fruit and vegetable discards preserved with sodium metabisulfite as a high-moisture ingredient in total mixed ration for ruminants: effect on in vitro ruminal fermentation and in vivo metabolism. Asian-Australas J Anim Sci 2020;33:446-55. https://doi.org/ 10.5713/ajas.19.0596

16. Ferreira ACH, Neiva JNM, Rodriguez NM, Campos WE, Borges I. Nutritional evaluation of pineapple industry byproduct as additive on elephant grass silage. Rev Bras Zootec 2009;38:223-9. https://doi.org/10.1590/S1516-359820090

\section{2}

17. Suksathit S, Wachirapakorn C, Opatpatanakit Y. Effects of levels of ensiled pineapple waste and pangola hay fed as roughage sources on feed intake, nutrient digestibility and ruminal fermentation of Southern Thai native cattle. Sonklanakarin J Sci Technol 2011;33:281-9.

18. Ferreira ACH, Rodriguez NM, Neiva JNM, et al. In situ degradability of elephant grass ensiled with increasing levels of pineapple agro-industrial by-product. Semin Cienc Agrar 2016;37(Suppl 4):2807. https://doi.org/10.5433/1679-0359

19. Weakley DC, Stern MD, Satter LD. Factors affecting disappearance of feedstuffs from bags suspended in the rumen. J Anim Sci 1983;56:493-507. https://doi.org/10.2527/jas1983.562493x

20. Nocek JE. Evaluation of specific variables affecting in situ estimates of ruminal dry matter and protein digestion. J Anim Sci 1985;60:1347-58. https://doi.org/10.2527/jas1985. $6051347 x$

21. Fadel JG. Application of theoretically optimal sampling schedule designs for fiber digestion estimation in sacco. J Dairy Sci 1992;75:2184-9. https://doi.org/10.3168/jds.S0022-0302 (92)77978-8

22. Uden P, Parra R, Van Soest PJ. Factors influencing reliability of the nylon bag technique. J Dairy Sci 1974;57(Suppl 1):358.

23. Mehrez AZ, Ørskov ER. A study of artificial fibre bag technique for determining the dig estibility of feeds in the rumen. J Agric Sci 1977;88:645-50. https://doi.org/10.1017/S0021 859600037321

24. Nocek JE, Russell JB. Protein and energy as an integrated system. Relationship of ruminal protein and carbohydrate availability to microbial synthesis and milk production. J Dairy Sci 1988;71:2070-107. https://doi.org/10.3168/jds. S0022-0302(88)79782-9

25. Nocek JE. Energy metabolism and rumen acidosis. In: Proceedings of the Tri-State Dairy Nutrition Conference; 1995. pp. 23-4.

26. Piao MY, Kim HJ, Seo JK, et al. Effects of synchronization of carbohydrate and protein supply in total mixed ration with Korean rice wine residue on ruminal fermentation, nitrogen metabolism and microbial protein synthesis in Holstein steers. Asian-Australas J Anim Sci 2012;25:1568-74. https:/doi.org/ 10.5713/ajas.2012.12379

27. Lahr DA, Otterby DE, Johnson DG, Linn JG, Lundquist RG. Effects of moisture content of complete diets on feed intake and milk production by cows. J Dairy Sci 1983;66:1891-900. https://doi.org/10.3168/jds.S0022-0302(83)82027-X

28. Robinson PH, Udén P, Wiseman J, Mateos GG. Some suggestions and guidelines for preparation of manuscripts for submission for consideration for publication. Anim Feed Sci Technol 2007;134:181-8. https://doi.org/10.1016/j.ani feedsci.2007.02.007

29. Lee MRF, Harris LJ, Moorby JM, et al. Rumen metabolism and nitrogen flow to the small intestine in steers offered 
Lolium perenne containing different levels of water-soluble carbohydrate. Anim Sci 2002;74:587-96. https://doi.org/10. 1017/S1357729800052747

30. Obara Y, Dellow DW, Nolan JV. The influence of energy-rich supplements on nitrogen kinetics in ruminants. In: Tsuda $\mathrm{T}$, Sasaki Y, Kawashima R, editors. Physiological aspects of digestion and metabolism in ruminants. Cambridge, MA, USA: Academic Press; 1991. pp. 515-39. https://doi.org/10.1016/ B978-0-12-702290-1.50029-1
31. Choi Y, Lee S, Na Y. Effects of a pineapple (Ananas comosus L.) cannery by-product on growth performance and carcass characteristics in the finishing stage of Hanwoo steer. AsianAustralas J Anim Sci 2020 Jul 2 [Epub]. https://doi.org/10. 5713/ajas.20.0234

32. Sruamsiri S. Agricultural wastes as dairy feed in Chiang Mai. Anim Sci J 2007;78:335-41. https://doi.org/10.1111/j.17400929.2007.00445.x 